\title{
ARCHAEOLOGICAL WORKS AND RESEARCHES BY G.V.GRIGORIEV AND A.I.TERENOZHKIN IN THE TERRITORY OF SAMARKAND SOGD IN THE FIRST HALF OF THE XX CENTURY
}

\author{
Gulnara Komilevna Farmanova
}

Senior Lecturer Department Of World History Of Fergana State University, Republic Of Uzbekistan

\section{ABSTRACT}

The author of the article claims that archaeological research and scientific research were carried out in Central Asia in the first half of the twentieth century, including the archaeological study of the Samarkand Sogd by G.V.Grigoriev and A.I.Terenozhkin. The article presents material on the directions of development of archaeological science in Uzbekistan and in Samarkand Sogd on the example of the work of prominent scientists and specialists who carried out archaeological excavations in the first half of the twentieth century. It also reveals the origins of the addition of archaeological research methodology at the stages of the formation and development of archeology. The author notes large archaeological expeditions and their achievements during the period under study. However, in addition to the merits and achievements in scientific theoretical and practical research, errors, lack of personnel, experience and methods for conducting archaeological excavations and research are shown.

KEYWORDS: - Uzbekistan, Samarkand Sogd, G.V. Grigoriev, A.I. Terenozhkin, archeology, archaeologists, history, ancient, historical sources, archaeological excavations, archaeological finds, archaeological methods, archaeological research, archaeological expedition, stratigraphy, periodization.

\section{INTRODUCTION}

Uzbekistan is a country of ancient civilization and rich culture, captured in written sources and monuments of material culture, testifying to the original and centuries-old history. On the territory of Uzbekistan, Sogd-Sogdiana is exceptionally distinguished, mentioned in the oldest parts of the Avesta as Gava Suguda, and in the written sources of Alexander the Great's campaigns in Sogdiana, with the capital city of Marakand. On the territory of Samarkand Sogd, there are more than 3,000 monuments, which were the ruins of cities, settlements, fortresses, castles of the agricultural population, and numerous burial mounds of nomadic pastoralists been preserved in the foothills. All the abovementioned archaeological sites, being a cultural heritage, are included in the golden fund of the historical past of the peoples of Uzbekistan. The Republic of Uzbekistan pays great attention to the study of its historical heritage.

Sogd, located in the center of the Central Asian interfluve and an important historical and cultural region, played an essential role in forming and developing transcontinental trade routes. One of the earliest agricultural cultures arose here, enriched thanks to close ties with the steppe tribes in vast areas, ranging from the Syr Darya and Aral steppes to the Urals in the north and Altai in the northeast. 
CURRENT RESEARCH JOURNAL OF HISTORY 2(11): 39-47, November

2021

DOI: https://doi.org/10.37547/history-crjh-02-11-09

ISSN 2767-472X

(C2021 Master Journals

Crossref doi

gil Google

Accepted 21 th November, 2021 \& Published $26^{\text {th }}$ November, 2021

\section{]Literature review}

Considering the degree of study of the topic, it is necessary first to dwell on the works of such authors as Grigoriev G.V. [5]; [6]; [7], Masson M.E. [14]; [15], Askarov A.A. [4], Isamiddinov M.Kh. [8]; [9]; [10], Kabanov S.K. [11]; [12], which provide data on the emergence of irrigated agriculture in the vicinity of Samarkand, presented materials on the periodization and origins of urban culture, considered the stratigraphy of Afrasiab, showed archaeological research and excavations of the monuments of Samarkand Sogd. In the works of O.V. Obelchenko [18]; [19]; [20]; [21]; [22], devoted to the archaeological research and excavation of the monuments of Afrasiab, the issues of specific historical periods in the history of ancient Samarkand are considered, the interaction of cultural traditions in the context of the direct influence of the geographical environment on the lifestyle of the population is shown. In the works of Filanovich M.I. [29]; [30], Shishkina V.A. [32], Shishkina G.V. [33]; [34] and other authors show the most ancient settlements on Afrasiab, the climatic conditions of the region, reflecting the economic and cultural interaction of the peoples of Sogd with neighboring and distant regions. Also, separate works of A.I. Terenozhkin require special attention. [26]; [27], which reveal aspects of the archaeological study of ancient Sogd, consider the issues of material culture, economic ties and settlements. The works used and several others make it possible to carry out a comparative analysis of the sources and their data and thereby provide information proving the history of the archaeological study of Samarkand and its environs in the first half of the twentieth century.

\section{ANALYSIS AND RESULTS}

From the 50-60s of the XX century, large archaeological expeditions began to be created throughout Central Asia. A separate archaeological expedition was organized to study the settlement of Penjikent. The Samarkand archaeological base is being created almost in parallel, the head of which is A.I. Terenozhkin. However, the minimal means for conducting archaeological excavations did not allow it to carry out systematic excavations on a large scale. As a result, A.I. Terenozhkin, on his own, cleared various precipices and gullies on the Afrasiab settlement, and having collected the necessary material, he was able to draw up a periodization of the history and culture of Samarkand.

The archaeological science of Central Asia as a whole and the Samarkand Sogd of the 30-40s of the twentieth century was enriched thanks to the works of an outstanding scientist - a native of the Leningrad school of orientalists G.V.Grigoriev. Before the archaeological works of G.V.Grigoriev, carried out in the Tashkent region, there were no other stratigraphic excavations in almost all of Central Asia. There was no such work on the territory of the city of Samarkand either. During the excavations, no methodological techniques were followed, because of which, after the "stratigraphic excavations" were carried out in Afrasiab, part of the monument fell into disrepair. As VA Shishkin writes, “... VL Vyatkin, working for many years at Afrasiab, only in the early thirties was able to distinguish the layers of the Kushan time, at the same time, while working in Termez of MI Vyazmitin, he could not recognize ceramics of the Kushan time" [32: p. 110].

The study of ceramics in the history of archeology has always been considered the most pressing issue. Any archaeologist working in the field tries to obtain archaeological material, observing all the rules of excavation work.

G.V. Grigoriev, who worked for several years in archaeological excavations in the Tashkent 
CURRENT RESEARCH JOURNAL OF HISTORY 2(11): 39-47, November

2021

DOI: https://doi.org/10.37547/history-crjh-02-11-09

ISSN 2767-472X

(C2021 Master Journals

conseset (d)

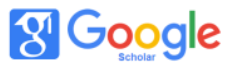

Accepted 21 th November, 2021 \& Published $26^{\text {th }}$ November, 2021

region in the mid-30s of the twentieth century, took part in exploration work in the vicinity of Samarkand and for several years excavated the Tali-Barzu settlement located in the southern part of the city [5: p.87-104]; [6: p.24-34]; [7: p.94-103]; [7: p. 150-153]. A.M. Belenitsky, V.A.Ilyinskaya, and other researchers from St. Petersburg took part in the excavations of this settlement. As a result of the excavations, a rich and varied material was obtained. These materials made it possible to obtain stratigraphically consistent complexes covering thousand years of history. Based on such material, G.V. Grigoriev was the first in the archeology of the central regions of Central Asia to create a stratigraphic column and develop a relative periodization of ceramic assemblies found during excavations.

The monument as an archaeological site was very successful. In this regard, the resulting complexes have become the subject of discussion among archaeologists and historians [26: p.156161]. G.V. Grigoriev identified six layers at this object. The layers and complexes highlighted on this site are correct and not a subject of discussion. However, about the dating of the identified complexes, they became the main subject of controversy among the archaeologists of Central Asia. This circumstance is because when G.V. Grigoriev was periodizing the material culture of the Tali-Barzu settlement, in the conditions of Central Asia, there were no such stratigraphically distinguished archaeological complexes. As a result, the oldest of them (TB-I) was attributed based on far inaccurate analogies with objects from Anau and materials from Kaunchitep that he incorrectly dated to the end of the first half of the first millennium BC. The TB-II complex is attributed to the "Achaemenid" time, i.e., the V-IV centuries BC. The third (TBIII), called "Hellenistic", is attributed to the III-II centuries BC - I century AD.
Regarding the fifth layer (TB-V), G.V. Grigoriev noticed that the upper part of this layer did not contain remnants of material culture, i.e., in his opinion, this feature indicated a break in the life of the settlement, which lasted for two-three centuries, in connection with which it was dated to the V-VII centuries AD.

The last sixth layer based on Sogdian coins (coins of Tarhun and "Bukhar-Khudats") is dated by G.V. Grigoriev at the beginning of the 8th century AD.

Of course, such a periodization of material culture carried out for the first time should have had a comprehensive response among scientists. Any other scientist who first tried to produce a chronological periodization of material culture could have had such an "approximate" date. It was G.V. Grigoriev, thanks to his diligence and observation, who obtained clean, stratigraphically consistent ceramic assemblies, which, as archaeological material, are the most successful and have not lost their significance to this day.

In the first years after the publication of data on the material culture of the Tuli-Barzu settlement, several scientific responses appeared [35]; [15]; [31: p.135-136]; [13]; [28: p.86]. Among the articles and monographs, the point of view of S.P. Tolstov and A.I. Terenozhkin stands out. S.P. Tolstov was one of the first to respond to the works of G. Grigoriev. He disagreed with the dating of the complexes of the Talli-Barzu settlement [28: p.85-86]. In particular, according to SP Tolstov, the materials TB-I - TB-IV are close to the Kushan layer of Termez and the complexes of the Kanguy and Kushan periods from Khorezm [28: p.86].

A sufficiently detailed and fractional dating was proposed by A.I. Terenozhkin, strongly rejecting the dating of the TB-I layer by the "preAchaemenid" time, referring it to the 2nd-1st 
CURRENT RESEARCH JOURNAL OF HISTORY 2(11): 39-47, November

2021

DOI: https://doi.org/10.37547/history-crjh-02-11-09

ISSN 2767-472X

(C2021 Master Journals

Crossref doi

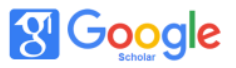

Accepted 21 th November, 2021 \& Published $26^{\text {th }}$ November, 2021

centuries. BC. He dates the next two layers to the Kushan time, i.e., 1st-4th centuries AD TB - IV is attributed to the Hephthalite, or even to the time of the reign of the Turkic Kaganate, i.e., to the VVI centuries. AD TB-V is dated based on the known assemblages from Afrasiab and Penjikent to the 7th - early 8th centuries. AD [26: p.156161]. Both the dating of G.V. Grigoriev and A.I. Terenozhkin were far from perfect, but his relative dates were very close to the real dates. However, he strongly rejected the too-deep dates of the TB-I complex, referring it to the Hellenistic period. During the work of G.V. Grigoriev, many new materials were obtained in Tajikistan, Khorezm, Bactria, southern Turkmenistan, and the studies of A.I. Terenozhkin Afrasiab were not known. However, despite this, only A.I. Terenozhkin could see the shortcomings of his colleague G.V. Grigoriev. Only A.I. Terenozhkin was familiar with the ceramic complexes of Afrasiab and its surroundings. Only he was able to synchronize them with the material culture of the settlement of Penjikent.

The main merit of G.V. Grigoriev was to establish the main features of the stratigraphy of the TuliBarzu settlement, as well as their relative chronology. Central Asian archeology at that time needed precisely such more accurate chronologically consistent complexes. The work of G.V. Grigoriev was one of the first steps in obtaining chronologically consistent ceramic complexes, compiling the periodization of the history of the material culture of Central Asia. The chronology proposed in the 30s at the TaliBarzu settlement became correct only after large expeditions carried out in Khorezm, Turkmenistan, Surkhandarya, and Afrasiab. The exceptional observation of G.V. Grigoriev made it possible to prove that the mountain river Ilansay, descending from the mountains, cuts through the channel of the Dargom canal. For this reason, he notes for the first time that the Dargom canal is an artificial canal; however, for the construction of the canal, the channels of mountain says (rivers) were used [8: p.10].

A primary researcher of the history and culture of Sogd, A.I. Terenozhkin, is an expert on the archaeological cultures of the multi-layered settlements and settlements of Central Asia. He is the first archaeologist to carry out archaeological excavations in Afrasiab in the post-war years. Since 1945, the Samarkand archaeological base was organized in Samarkand, which was entrusted to A.I. Terenozhkin.

Difficulties in the living conditions of the postwar years and insufficient funding for the maintenance of the archaeological base and the expedition forced A.I. Terenozhkin to carry out archaeological excavations in Afrasiab on his own, by clearing old excavations, ravines and especially open-pit mines. For several years, this indefatigable archaeologist was able to trace the stages of the formation and development of urban life on Afrasiab and the development of material culture in general.

By cleaning the walls of ravines and gullies, A.I. Terenozhkin collected a large and varied archaeological material, managed to systematize it and build on its basis the periodization of ancient and medieval Samarkand also isolated several stratigraphic complexes [27]; [26]. According to experts, it is believed that A.I. Terenozhkin was mistaken in his conclusions. However, these shortcomings in many cases are explained by the lack of specific materials and the limited archaeological excavations. In particular, his conclusion about the decline of urban life in the first centuries of our era was not confirmed since the prosperity of urban life in the first centuries of our era in the Kashkadarya valley was traced [9]; [10]; [25].

Of course, not all major and global problems are solved instantly or in one go. The most important 
CURRENT RESEARCH JOURNAL OF HISTORY 2(11): 39-47, November

2021

DOI: https://doi.org/10.37547/history-crjh-02-11-09

ISSN 2767-472X

(C2021 Master Journals

\section{Crossref do) 8 Google}

Accepted 21 th November, 2021 \& Published 26 ${ }^{\text {th }}$ November, 2021

thing is that A.I. Terenozhkin was the first to raise the problem of periodization of the history and culture of Samarkand Sogd. However, such a great work, which is the periodization of the history and culture of a separate historical and cultural region, in particular, the Samarkand Sogd or the entire Sogdiana, in the first attempt was not completed the first time. As a result, there were small gaps in the periodization of the history and culture of Afrasiab, errors in the establishment of specific dates. Numerous articles have appeared indicating the shortcomings of the periodization of the history and culture of Samarkand. In particular, in 1950, M.E. Masson, in an article devoted to the periodization of the history and culture of Samarkand, represents the territory of ancient Samarkand within the "Devori Kundalyang". In his opinion, "the ancient authors considered the outer wall of Marakanda to be 70 stades long" [14].

In addition, in 1946, A.I. Terenozhkin, together with L.I. Albaum carried out reconnaissance work in the vicinity of Samarkand, although both of them were included in the Amu Darya expedition. In addition, starting from the 50s of the twentieth century, separate excavation work began on the territory of the Samarkand region. In particular, B.Ya. Stavissky excavates the settlement of Kuldortepa, located $35 \mathrm{~km}$ southeast of the city of Samarkand. On this monument, he discovered layers of the 2nd-1st centuries. BC. - 1st c. AD [24].

Since 1958, the Afrasiab archaeological expedition has been created under the leadership of V.A. Shishkin. This was a new stage in the study of Afrasiab, which in turn is subdivided into two short periods. The first of them coincides with the release of the government decision "On declaring Afrasiab a State Reserve and the creation of an archaeological expedition." The study of the settlement of Afrasiab was always a very complex archeological process, since here the life of the population always continued intensively, which led to a significant destruction of the cultural layers (sometimes to the point of complete foundation). This circumstance led to many opinions about the initial dates of city life and the area of the original city. There were cases of erroneous interpretation of the fortifications of Afrasiab [23].

Over the years, such well-known scientistsarchaeologists as T.R.Agzamkhodzhaev, D.I.Varkhotova, V.D. Zhukov, S.K.Kabanov, O.V. Obelchenko, G.V. Shishkina, L.G.Brusenko, Ya.K. Kriks, Yu.F. Buryakov, M.Kh. Urmanova, Sh.Tashkhodzhaev, N.B. Nemtseva, M.I. Filanovich and others worked as part of the expedition.

The expedition staff paid immediate attention to the stratigraphy and topography of Afrasiab. In particular, N.B. Nemtseva concentrated her preliminary work on the southern part of the settlement. Having laid pits in several places of Afrasiab, she revealed the lower layers, dating them to the 6th-5th centuries BC. [17: p. 153205]. In the same years, M.I. Filanovich laid a stratigraphic pit in a reservoir to the west of the cathedral mosque of Afrasiab and proved that in the lower layers of a large reservoir - the khauz, there are traces of an ancient settlement of the 7th century BC. [29: p. 206-220]. Later, this conclusion was clarified and a small pit was laid at this object [30: p.85-95].

On the territory of Samarkand Sogd, reconnaissance groups also worked to identify settlements. However, judging by the identified monuments, most of all were discovered monuments of the Middle Ages. Of course, there were also monuments dating back to the $2 \mathrm{nd}-1 \mathrm{st}$ centuries BC. - 1st century AD, but they were in isolated cases. 
CURRENT RESEARCH JOURNAL OF HISTORY 2(11): 39-47, November

2021

DOI: https://doi.org/10.37547/history-crjh-02-11-09

ISSN 2767-472X

(C2021 Master Journals

\section{Crossref dol}

\section{Google}

Accepted $21^{\text {th }}$ November, 2021 \& Published $26^{\text {th }}$ November, 2021

The Zarafshan River was the main waterway of the Samarkand and Bukhara Sogd. In the same years, A.R. Mukhamedzhanov researched the irrigation system of the entire Zarafshan valley of Sogd [16]. However, at the same time, he focused on the Bukhara oasis.

Continuing the work of G.V. Grigoriev and A.I. Terenozhkin, great success in the study of the stratigraphy of the ancient period of Afrasiab was achieved by S.K. Kabanov [11: p.183-198]; [12: p.16-84] and G.V. Shishkina [33: p.6-20]; [34: p. 221-246]. It is these two experienced archaeologists who have achieved tremendous success in dating the ceramic assemblies.

On the territory of the Samarkand region, archaeologist O.V. Obelchenko carried out archaeological work to study the burial mounds of the cattle-breeding population [18: p.4-20]; [19: p.97-176]; [20: p.57-70]; [21: p.66-81]; [22: p.69]. However, analyzing the works of O.V. Obelchenko, it becomes clear that he does not comply with the main criteria - to be always as accurate as possible and not to miss any finds that can provide historical information. In the publications of O.V. Obelchenko, there are no photographs, maps, and diagrams, and no interpretation of the materials is given. Many of these mounds are currently missing, and the excavated mounds are no longer possible to restore.

While performing prospecting work on the territory of the Urgut region, A.A. Askarov discovered the Muminabad burial mound dating back to the Bronze Age. This gave a great impetus to understanding the late stages of the Bronze Age [4: p.56-62].

N.A. Avanesova can be attributed to significant archaeologists studying the pastoralist population of the Bronze Age. For many years she lectured at the Department of Archeology of Samarkand State University, and all practical work with future archaeologists was carried out along the steep banks of the Dargom and Zarafshan canals, thanks to which she achieved great success in this field. N.A. Avanesova discovered many burial mounds or the location of tribes of the Bronze Age precisely during practical studies with future archaeologists. In particular, the burial ground "Siyobcha", located directly on Afrasiab, "Chakka", located on the left bank of the Zarafshan River, a metallurgical workshop - the settlement of Tugaynoye, located on the left bank of the Zarafshan River, and a cult center [1: p.16-19]; [2: p.27-28]; [3: p.77-198].

\section{Conclusion}

When analyzing the archaeological research of Samarkand Sogd in the first half of the 20th century, it is striking that at the stage of the formation and development of archaeological science, the work of individual archaeologists was carried out. Archaeologists mainly paid attention to the identification, registration, and systematization of monuments and the compilation of primary maps. Special attention was paid to the exploratory study of the most significant monuments of individual oases. In general, the first half of the twentieth century was the era of the formation and formation of archaeological science in Uzbekistan. With the creation in the early $30 \mathrm{~s}$ in the twentieth century, significant expeditions experienced an acute shortage of archaeological personnel, which was raised before the government. In this regard, on April 1, 1940, at the Faculty of History of the Central Asian University, the Department of Archeology was created under the leadership of M.E. Masson.

The works of G.V. Grigoriev, A.I. Terenozhkin, and several significant archaeologists in the first half of the twentieth century are among the main achievements in the historical and archaeological 
CURRENT RESEARCH JOURNAL OF HISTORY 2(11): 39-47, November

2021

DOI: https://doi.org/10.37547/history-crjh-02-11-09

ISSN 2767-472X

(C)2021 Master Journals

\section{Crossref doi) 81 Google}

Accepted 21 ${ }^{\text {th }}$ November, 2021 \& Published $26^{\text {th }}$ November, 2021

study of the Samarkand Sogd. These archaeological works and research have brought in new exciting data on the history of the material culture of Samarkand and Samarkand Sogd and showed the prospects of studying this region for the reconstruction of the history and culture of Central Asia as a whole.

\section{References}

1. Avanesova N.A. On the clothing of the cattle-breeding tribes of the Bronze Age of Central Asia. / Questions of archeology, ancient history and ethnography. Samarkand: SamSU, 1981.

2. Avanesova N.A. At the origins of the Silk Road. Formation and development of the routes of the Great Silk Road in Central Asia in antiquity and the Middle Ages. / Abstracts of the UNESCO International Seminar. Samarkand, October 1-6, 1990 - T . Fan, 1990.

3. Avanesova N.A. The culture of the shepherd tribes of the Bronze Age of the Asian part of the USSR (for metal products). -T .: Fan, 1991. -200 s.

4. Askarov A.A. Excavation of a Bronze Age burial ground in Muminabad. YMCU. Collection "Afrasiab", issue VIII. -T .: 1969.

5. Grigoriev G.V. Settlement Tully-Barzu. TOVE. Volume II. -L .: 1940.

6. Grigoriev G.V. Settlements of ancient Sogd. KSIIMK, IV. -L .: 1940.

7. Grigoriev G.V. Tully-Barzu as a monument of pre-Muslim Sogd. KSIIMK, 12.-L .: 1946.

8. Isamiddinov M.Kh. The origins of the urban culture of Samarkand Sogd (problems of interaction of cultural traditions in the era of the Early Iron Age and in the period of antiquity). -T .: 2002.
9. Isamiddinov M.Kh., Suleimanov R.Kh. Yerkurgan (stratigraphy and periodization). -T .: Fan, 1984.

10. Isamiddinov M.Kh., Khasanov M.Kh. History of ancient and medieval ceramic production in Nakhshab. -T .: 1991.

11. Kabanov S.K. Study of the stratigraphy of the Afrasiab settlement. CA. \# 1. -M .: 1969.

12. Kabanov S.K. Stratigraphic excavation in the northern part of Afrasiab. Afrasiab. Collection "Afrasiab", issue II. -T .: 1973.

13. Knipovich T.N. Some questions of dating of the Central Asian ceramics of the preMuslim period. KSIIMK, XXVIII. -M .: 1949.

14. Masson M.E. On the periodization of the ancient history of Samarkand. VDI, No. 4. M .: 1950 .

15. Masson M.E. Archaeological research in Uzbekistan, in the book "Science in Uzbekistan for 15 years". -T .: 1939.

16. Mukhamedzhanov A.R. The history of irrigation of the Bukhara oasis (from ancient times to the beginning of the 20th century). $-\mathrm{T} .: 1979$.

17. Nemtseva N.B. Stratigraphy of the southern outskirts of Afrasiab. Collection "Afrasiab", issue I. -T .: 1969.

18. Obelchenko O.V. Kuyu-Mazarskiy and Lyavandakskiy burial ground. Abstract of the dissertation for the degree of candidate of historical sciences. $-\mathrm{T}$.: 1954. -20 p.

19. Obelchenko O.V. Lyavandak burial ground. YMCU. Collection "Afrasiab", issue II. -T .: 1961.

20. Obelchenko O.V. Burial ground Akjar-Tepe. YMCU. Collection "Afrasiab", issue III. -T .: 1962.

21. OV Obelchenko Sazagan burial mounds. 
CURRENT RESEARCH JOURNAL OF HISTORY 2(11): 39-47, November

2021

DOI: https://doi.org/10.37547/history-crjh-02-11-09

ISSN 2767-472X

(C2021 Master Journals

\section{Crossref doi) 81 Google}

Accepted 21 ${ }^{\text {th }}$ November, 2021 \& Published $26^{\text {th }}$ November, 2021

YMCU. Collection “Afrasiab”, issue VII. -T .: 1966.

22. OV Obelchenko Saki burial mounds in the Zarafshan valley. / Abstracts of reports and messages for the meeting "Problems of archeology of Central Asia." -L .: 1968.

23. Pachos M.K. Defensive structures of Afrasiab. Abstract of the dissertation for the degree of candidate of historical sciences. $-\mathrm{T}$.: 1966.

24. Stavisky B.Ya. Excavations of the Kuldortepa settlement in 1956-1957 CA. No. 4. -M .: 1960.

25. Suleymanov R.Kh. Ancient Nakhshab. Problems of ancient civilizations of Uzbekistan in the 7th century BC. - VII century. AD -T .: Fan, 2000.

26. Terenozhkin A.I. Sogd and Chach. Abstract of the dissertation for the degree of candidate of historical sciences. -M .: 1950.

27. Terenozhkin A.I. Questions of historical and archaeological periodization of ancient Samarkand. - VDI, No. 4. -M .: 1947.

28. Tolstov S. P. Ancient Khorezm. -M .: 1948.

29. Filanovich M.I. To the characteristics of the oldest settlement on Afrasiab. Collection "Afrasiab", issue I. -T .: 1969.

30. Filanovich M.I. On the history of the formation of the city fortifications of Afrasiab. Collection "Afrasiab", issue II. -T .: 1973 .

31. Freiman A.A. The oldest Sogdian inscription. VDI. No. 3. -M: 1939.

32. Shishkin V.A. On the history of the archaeological study of Samarkand and its environs. Collection "Afrasiab", issue I. -T .: 1969. -339 p.

33. Shishkina G.V. Ancient Samarkand in the light of the stratigraphy of the western regions of Afrasiab. Abstract of the dissertation for the degree of candidate of historical sciences. -T .: 1969.

34. Shishkina G.V. Materials of the first centuries $\mathrm{BC}$ from excavations in the north-west of Afrasiab. Collection "Afrasiab", issue I. -T .: 1969.

35. Yakubovsky A.Yu. A short field report on the work of the Zarafshan archaeological expedition of the Hermitage and the IIMK in 1939.

36. Yuldashev S.B. Ferghana in the VII century: It's development as a powerful state and its collapse // History Reseach Journal. 2019 vol. 5. Issue 6. - P. 2952-2964.

37. Yuldashev S.B. Samanids of Ferghana // International journal for social studies. 2020. vol. 6. Issue 01. - P. 120-135.

38. Yuldashev S.B. The impact of the Aksu battle on Ferghana // ERPA International Journal of Research and Development. 2020. Vol. 5 (8). P. 60-64. DOI: https://doi.org/10.36713/epra4917

39. Yuldashev S.B. Early arab invasions of Fergana // «Евразийский Союз Ученых» научный журнал. - Москва, - 2020. - № 8 (77/4). - P. 31-35.

40. Isamiddinov $\mathrm{M}$. The history of emergence of Sughd Cities // EPRA International Journal of Research and Development. Volume:5, Issue:10, October 2020 India. P. 125-128.

41. Mirsoatova S.T. New data on the late paleolithic of the Fergana valley // Евразийский союз ученых (2020. - № 10 (79/4). - P. 25-29.

42. Farmanova G.K. The role of the geographic environment and climatic conditions in the 
formation of economic-cultural type of population when during ancient and antic period // ACADEMICIA: An International Multidisciplinary Research Journal. Vol. 10, Issue 11, November 2020. - P. 1612-1622. Impact Factor: SJIF $2020=7.13$. DOI: 10.5958/2249-7137.2020.01639.0.

43. Rakhmatillayev H. Ethnodynamics of the city population of the Fergana valley of the first half of the XX century // EPRA International Journal of Research and Development. Volume: 5, Issue:5, May 2020. - P. 532-535.

44. Arslonzoda R. Memoirs as asourse on the history of Uzbekistan in the second half of the 19th - early 20th centuries // EPRA International Journal of Research and Development. Volume: 5, Issue:10, October 2020. - P. 119-124.

45. Mahmudov 0 . The beginning of the European renaissance. ERPA International Journal of Research and Development. 2020; Vol. 5 (7). - P. 104-108. DOI: https://doi.org/10.36713/epra4787

46. Yuldashev S. Visit of chinese ambassador dung wan to Fergana // The history of the Fergana valley in new researches. Fergana, 2021. - P. 123 - 131. https://doi.org/10.47100/conferences.v1i 1.1240

47. Khamayev N.M. The essence of the armed struggle against soviet power in Turkestan in the interpretation of journalists // Asian Journal of Multidimensional Research (AJMR). 2020. - Vol-09. Issue-11, November 2020. - P. 146-150.

48. Rasulov M. Archival documents on turkestan autonomy as a historical source (on the example of documents from the Fergana regional state archive): https://doi. org/10.47100/conferences. v1i1. 1267 